\title{
Hepatitis B, C, and D virus and human T- cell leukemia virus types 1 and 2 infections and correlates among men who have sex with men in Ouagadougou, Burkina Faso
}

Henri Gautier Ouedraogo ${ }^{1,2,3^{*}}$ (D), Seni Kouanda ${ }^{1,3}$, Ashley Grosso $^{4}$, Rebecca Compaoré ${ }^{1}$, Modibo Camara ${ }^{1}$, Charlemagne Dabire ${ }^{1}$, Rasmata Ouedraogo ${ }^{2}$, Yves Traore $^{2}$, Stefan Baral ${ }^{4}$ and Nicolas Barro ${ }^{2}$

\begin{abstract}
Background: Men who have sex with men (MSM) are considered to be at significant risk for sexually transmitted infections (STI) and bloodborne viruses including viral hepatitis types $B, C$, and D (HBV, HCV, and HDV) and human T-cell leukemia virus types 1 and 2 (HTLV 1\&2). This study aimed to assess the seroprevalence and correlates of HBV, HCV, HDV, and HTLV $1 \& 2$ antibodies among MSM in Ouagadougou, Burkina Faso.

Methods: We conducted a cross-sectional survey to assess the biological and behavourial characteristics among MSM in Ouagadougou from January to April 2013. Serum specimens obtained were tested for the presence of HBV, HCV, HDV and HTLV-1\&2 infections. MSM 18 years and older were recruited using respondent driven sampling (RDS). Population estimates and 95\% confidence intervals (Cl) adjusted for the RDS design were calculated using RDS Analysis Tool (RDSAT) version 6.0.1 (RDS, Inc., Ithaca, NY). Bivariate and multivariate logistic regression analyses were conducted to assess correlates of these infections using Stata 14.

Results: A total of 329 MSM were tested. Prevalence was $20.4 \%$ (95\% Cl: 16.4-25.1) for HBV, 11.0\% (95\% Cl: 8.0-14.8) for $\mathrm{HCV}$, and $0.0 \%$ for HDV. Anti-HTLV $1 \& 2$ antibodies were found in 4.0\% (95\% Cl: 2.3-6.8) of MSM. Factors independently associated with HBV infection were lack of condom use during the last anal sex act with a main male sexual partner and experience of condom tearing during anal sex. Presence of anti-HTLV $1 \& 2$ antibodies was associated with history of genital or anal lesions and injection drug use. None of the variables included in our study were associated with HCV.

Conclusions: This study shows that HBV, HCV and HTLV 1\&2 prevalence among MSM in Burkina is high and suggests that comprehensive STI prevention and sexual health education services for this group are needed.
\end{abstract}

Keywords: HBV, HCV, HDV, HTLV 1\&2, MSM, Burkina Faso, West Africa

\section{Background}

Many men who have sex with men (MSM) are at a higher risk of contracting sexually transmitted infections (STI) and bloodborne pathogens [1-4]. These infections include Hepatitis B, C, and D viruses (HBV, HCV, and HDV) [5-12] and human T-cell leukemia virus types 1 and 2 (HTLV 1\&2) [13, 14]. Hepatitis viruses are responsible for

\footnotetext{
* Correspondence: gouedraogo@irss.bf; whgautier@yahoo.fr

${ }^{1}$ Biomedical and Public Health Department, Institut de Recherche en Sciences de la Santé (IRSS), Ouagadougou 03BP7192, Burkina Faso ${ }^{2}$ University Ouaga1 Joseph Ki-Zerbo, Ouagadougou, Burkina Faso Full list of author information is available at the end of the article
}

96\% of the 1.34 million deaths related to cirrhosis and liver cancer [15]. HBV and HDV transmission are due to the presence of the virus in biological fluids (blood, semen, and vaginal secretions) of the infected individual $[16,17]$.

$\mathrm{HCV}$ is mainly transmitted through blood via blood transfusion in developing countries and via sharing syringes for injection drug use in developed countries [18]. However, recent studies show there is sexual transmission of HCV among MSM [19]. Studies from Europe have shown an increase in $\mathrm{HCV}$ incidence among MSM. In Switzerland, for example, HCV annual incidence among MSM increased from 0.23 (95\% Confidence Interval [CI]:

(c) The Author(s). 2018 Open Access This article is distributed under the terms of the Creative Commons Attribution 4.0 International License (http://creativecommons.org/licenses/by/4.0/), which permits unrestricted use, distribution, and 
0.08-0.54) cases per 100 person-years in 1998 to 4.09 (95\% CI: 2.57-6.18) cases per 100 person-years in 2011, compared to a change from 13.5 cases per 100 person-years to less than 1 case per 100 person-years among people who inject drugs [20].

HTLV is an infectious oncogenic retrovirus [13, 14] causing an aggressive cancer called adult T-cell leukemia/ lymphoma (HTLV 1) [21] and neurological manifestations (HTLV 2) [13, 22]. HTLV 1\&2 can be transmitted from mother to child, parenterally (through sharing needles or syringes), or sexually [23-25]. High morbidity of HTLV $1 \& 2$ has been found among populations at risk such as people who inject drugs and MSM [14, 26-28]. More than 20 million people are infected by HTLV $1 \& 2$ worldwide, and West Africa is considered a highly endemic area [23].

In Sub-Saharan Africa, very few data exist on hepatitis $\mathrm{B}, \mathrm{C}$, and D as well as on HTLV 1\&2 epidemiology among MSM. This study aimed to assess the seroprevalence and correlates of hepatitis B, C and D virus and anti-HTLV 1\&2 antibodies among MSM, a high-risk population in Burkina Faso.

\section{Methods}

\section{Study design}

A cross-sectional survey was conducted among MSM recruited using respondent driven sampling (RDS). RDS is a peer-recruitment sampling method designed to collect rigorous, representative data from hard-to-reach populations [29-31]. In preparation for this first integrated biological and behavioral survey, formative pre-survey research was conducted using formal meetings with MSM, local organizations, and government officials to explore MSM's willingness to recruit their peers, challenges in finding diverse segments of this hidden population, and preferences expressed by MSM for all study procedures. The results of these meetings suggested that RDS should be used for the survey.

\section{Setting}

The survey took place in Ouagadougou, the capital of Burkina Faso, a West African country with limited resources and high burden of viral hepatitis B and C.

\section{Study population and recruitment}

MSM were eligible to participate if they meet the following criteria: (i) at least 18 years old, (ii) assigned male gender at birth, (iii) reported anal sex with a man at least once in the past 12 months, (iv) able to provide informed consent in French, Mòoré, or Dioula, (v) had a valid coupon, (vi) lived in Ouagadougou for at least the past three months, and (vii) agreed to complete a behavioral questionnaire and human immunodeficiency virus (HIV) testing.

Recruitment chains were initiated by MSM seeds. Six MSM seeds were purposely selected. Seeds were chosen who met the study eligibility criteria, represented diverse demographics (age, education, marital status, language, and HIV status), and who were willing to promote the study.

After giving informed consent, seeds were required to complete a questionnaire and have their blood drawn. These seeds were each provided with three coded coupons which were valid for four weeks to recruit MSM peers from their social network. Individuals who were recruited by seeds and enrolled in the study were then provided with three coded coupons for further recruitment of peers. This process continued until the target sample size was reached.

Participants received male condoms, condom-compatible lubricants, HIV education materials, and information regarding existing services. They also received 2000 XOF ( $\sim 4$ United States dollars [USD]) for their time and transportation costs for each study visit. Per successfully eligible peer recruited to be part of the study (for up to three peers), recruiter had received 1500 XOF ( $\sim 3$ USD). To avoid individuals participating multiple times, a single study office was used in addition to the use of a unique identification code. Study staff included a site manager, a coupon manager, two data collectors, an HIV and STI test counselor, and a lab technician. All staff were trained in the study procedures to avoid duplicate enrollments.

\section{Sample size}

Sample size was previously estimated from an HIV behavior and seroprevalence study. The recruitment framework entailed 350 MSM. This size calculation was based on the assumption that populations who always use condoms have a $75 \%$ lower HIV prevalence than populations who do not, and the effectiveness of condoms is roughly $80 \%$, with $73 \%$ used as a conservative estimate [32]. Overall, HIV prevalence was estimated at $15 \%$ with $19 \%$ prevalence among those who did not consistently use condoms. A design effect of 1.5 associated with RDS, significance level of 0.05 , and a power of $80 \%$ was used.

\section{Data collection}

Data were collected from January to April 2013 in Ouagadougou. Following informed consent, MSM participants completed interviewer-administered face-to-face questionnaires in a private room. Information included sociodemographic characteristics of participants, partnerships and sexual behaviors (with men and women), condom use, knowledge, attitudes and practices related to STI, and injection drug use.

\section{Samples collection and laboratory methods for testing}

A trained nurse and lab technician respectively conducted HIV/STI counseling, venous blood specimen collection and HIV and syphilis testing in the study office. Serum 
samples were stored at $-20^{\circ} \mathrm{C}$ et transported to the laboratory for hepatitis B, C, D and HTLV testing using DiaPro Enzyme Linked Immunoassay (ELISA) methods (https://www.diapro.it,). All tests were performed according to the manufacturer's instructions.

\section{HBV testing}

The ELISA test kit HBsAg One version ULTRA (ULTRADia.Pro, Diagnostic BioProbes Srl, Italy), able to detect HBV " $s$ " mutant was used for hepatitis B surface antigen detection. This test uses a mix of mouse monoclonal antibodies specific to determinants "a", "d", and "y" of HBsAg fixed to the surface of microwells. For test procedure, $150 \mu \mathrm{l}$ of serum were added to the microwell together with $100 \mu \mathrm{l}$ of a second mix of mouse monocolonal antibodies, conjugated with Horseradish Peroxidase (HRP) and directed against a different epitope of the determinant "a" and against "preS". The specific immonocomplex, formed in the presence of HBsAg in the sample, is captured by the solid phase. At the end of of the one-step incubation for $120 \mathrm{~min}$ at $37^{\circ} \mathrm{C}$, microwells were washed to remove unbound serum proteins and HRP conjugate. Then $200 \mu \mathrm{l}$ of chromogen/substrate (tetra-methyl-benzidine and hydrogen peroxidase, $\mathrm{TMB} / \mathrm{H} 2 \mathrm{O} 2 \mathrm{mix}$ ) were added and incubate for $30 \mathrm{~min}$ at room temperature. In the presence of captured HBsAg immunocomplex, the colorless substrate is hydrolyzed by the bound HRP conjugate to a colored end-product. After blocking the enzymatic reaction by adding $100 \mu \mathrm{l}$ of sulfuric acid, its optical density was measured with the ELISA reader (Reader 270, Microelisa system, Biomerieux, France) using $450 \mathrm{~nm}$ filter for raiding and a $620 \mathrm{~nm}$ filter for background subtraction. by the ELISA reader. The color intensity is proportional to the amount of HBsAg present in the sample.

\section{HDV testing}

HBsAg reactive samples were subsequently tested for detection of anti-HDV antibodies using HDV Ab Dia.Pro, Diagnostic BioProbes Srl, Italy test kit, a competitive ELISA methods. The antibodies present in the serum compete with a virus-specific polyclonal IgG, labelled with peroxidase (HRP), for a fixed amount of rec-HDV coated on the microplate. The test was carried out with two steps incubation competitive system. First the $100 \mathrm{ul}$ of sample were added to the plate and specific anti-HDV antibodies bind to the adsorbed antigen and incubated for $60 \mathrm{~min}$ at $37^{\circ} \mathrm{C}$. After washing ( $4-5$ cycles), $100 \mu \mathrm{l}$ of an enzyme conjugate antibody to HDV were added and binds to the free portion of antigen coated, following by second incubation for $60 \mathrm{~min}$ at $37^{\circ} \mathrm{C}$. After washing, $100 \mu \mathrm{l}$ of chromogen/substrate mixture (TMB/H2O2 mix) was dispensed and incubated for $20 \mathrm{~min}$ at lab temperature $\left(25^{\circ}\right)$. The concentration of the bound enzyme on the solid phase becomes inversely proportional to the amount of
anti-HDV antibodies in the sample and its activity was detected by the added chromogen/substrate. After blocking the enzymatic reaction by addition of $100 \mu \mathrm{l}$ of sulfuric acid, the optical density was measured with the ELISA reader using a $450 \mathrm{~nm}$ filter for raiding and a $620 \mathrm{~nm}$ filter for background subtraction. The concentration of of HDVspecific antibodies in the sample is determined by means of a cut-off value that allowed for the semi-quantitative detection of anti-HDV antibodies.

\section{HCV testing}

For anti-HCV antibodies, the fourth generation ELISA HCV Ab-Dia.Pro test (Diagnostics BioProbes Srl, Italy) was used. This test kit uses microplates coated with $\mathrm{HCV}$-specific antigens derived from "core" and " $\mathrm{n}$ " regions encoding for conservative and immunodominant antigenic determinants (core peptide, recombinant NS3, NS4 and NS5 peptides). The solid phase was first treated with the diluted sample $(200 \mu \mathrm{l}$ diluent $+10 \mu \mathrm{l}$ sample) and incubated à $37^{\circ} \mathrm{C}, 45 \mathrm{~min}$. $\mathrm{HCV}$ antibodies were captured, if present, by the antigens. After washing out all the other components of the sample, in the second incubation ( 45 min, $37^{\circ} \mathrm{C}$ ) bound $\mathrm{HCV}$ antibodies, immunoglobin $\mathrm{G}$ and $\mathrm{M}$ as well, were detected by addition of $100 \mathrm{ul}$ of polyclonal specific and hIgG\&M antibodies, labelled with peroxidase (HRP). The enzyme captured with on the solid phase, acting on the chromogen/substrate mixture (100ul of $\mathrm{TMB} / \mathrm{H} 2 \mathrm{O} 2$ ), generates an optical signal that was proportional to the amount of anti $\mathrm{HCV}$ antibodies present in the sample. After incubation at lab temperature $\left(25^{\circ} \mathrm{C}\right)$ for $15 \mathrm{~min}, 100 \mu \mathrm{l}$ of sulfuric acid were added into each well to stop the enzymatic reaction. The optical density was measured with the ELISA reader using $450 \mathrm{~nm}$ filter for raiding and a $620 \mathrm{~nm}$ filter for background subtraction. A cut-off value let densities was interpreted into $\mathrm{HCV}$ antibodies negative and positive results.

\section{HTLV $1 \& 2$ testing}

Anti-HTLV 1\&2 antibodies were tested using the ELISA HTLV 1\&2 Ab-Dia.Pro ULTRA version (Diagnostic BioProbes Srl, Italy). This test uses microplates coated with HTLV1\&2 specific synthetic immunodominant antigens derived from gp46-1, gp46-II and gp21-I. The solid phase was first treated with the sample $(100 \mu \mathrm{l})$ and anti-HTLV 1\&2 antibodies are captured during incubation (for $45 \mathrm{~min}$ at $37^{\circ} \mathrm{C}$ ) by the antigens coated on the microplate. After washing out all the other components of the sample, in the second incubation for $45 \mathrm{~min}$ at $37^{\circ} \mathrm{C}$, bound anti-HTLV $1 \& 2$ total antibodies was detected by the addition $100 \mu \mathrm{l}$ of specific synthetic antigens derived from gp46-1, gp46-II and gp21, labelled with peroxidase (HRP). The enzyme captured on the solid phase, acting on the chromogen/substrate mixture, generates an optical 
signal that is proportional to the amount of anti HTLV $1 \& 2$ antibodies present in the sample. After blocking the enzymatic reaction, its optical density was measured by the ELISA reader (OD $450 \mathrm{~nm}$ ).

For each testing, manufacturer negative and positive controls, and calibrator were used. The results were calculated by the means of a cut-off value (Co) determined on the mean optic density (OD) $450 \mathrm{~nm}$ value of the negative control as recommended in the kit manufacturer procedure. The test results were interpreted as positive when a ratio of the samples optic density at $450 \mathrm{~nm}(\mathrm{~S})$ and the cut-of-value (Co) was superior to 1.1. Assay procedure was repeated for sample with equivocal result $(\mathrm{S} / \mathrm{Co}=0.9$ to 1.1$)$. All repeated testing provided negative or positive result and have been considered.

\section{Data processing}

Data were entered using EpiData 3.1 (The EpiData Association, Odense, Denmark) and exported into Stata 14 (StataCorp, College Station, TX) for analysis.

Descriptive statistics were used to describe participants' characteristics, HBV, HCV, HDV and HTLV 1\&2 seroprevalence, and sexual behaviors. All proportions were adjusted to account for the RDS method. This adjustment takes into consideration the probability of each participant to be included in the study. This probability was measured through weighting based on the size of each participant's network. Network size was determined using the survey question: "How many different people do you know personally who are MSM? i.e., you know them and they know you, you have seen them in the last 2 years, and you could contact them if you needed to?" The mean network size of study participants was 17 (minimum $=1$ and maximum $=600$ ). Population estimates and 95\% CI adjusted for the RDS design were produced using the RDS Analysis Tool (RDSAT) version 6.0.1 (RDS, Inc., Ithaca, NY).

Bivariate and multivariate logistic regression analyses were conducted to assess factors associated with testing positive for each of the infections (HBV, HCV, HDV, and HTLV 1\&2). Variables significantly associated with the infection at the $p<0.20$ level were included in the multivariate models.

\section{Ethical considerations and protection of the participants}

The study received ethical approval from the Ethics Committee for Health Research (CERS) of Burkina Faso. The study was implemented in a secure setting, and questionnaires were conducted in a private office. Collection of blood samples was performed by a trained staff member. Research ethic and sensitivity training were provided to all study staff before study implementation. Confidentiality was maintained by using a unique study identifier rather than real names on questionnaires and all study materials, protecting all electronic data with passwords, and storing hard copies of data in locked cabinets. Participant unique and anonymized codes were used to link study questionnaires with blood samples. All participants who tested positive for HIV were referred to a healthcare center.

\section{Results}

A total of 329 sera of MSM including original seeds were tested for hepatitis B, C, and D virus and HTLV 1\&2 infections.

\section{Socio-demographic characteristics}

Participants' socio-demographic characteristics are presented in Table 1. The mean age was $22.9 \pm 4.0$ years. In terms of sexual orientation, $71.9 \%$ (95\% CI: 66.7-76.5) of MSM reported being gay/homosexual. Less than half of the study participants were bisexual $(44.1 \%$; $95 \% \mathrm{CI}$ : 38.9-48.9). A minority (2.1, 95\% CI: 0.0-4.4) were transgender. The majority of study participants were single (94.6, 95\% CI: 91.6-96.5). Most of them were born in Burkina Faso. Over 70\% (71.8, 95\% CI: 66.8-76.4) of the participants recruited were students or pupils, while employees represented 21.6\% (95\% CI: 17.3-26.3).

\section{HBV, HCV, HDV and HTLV $1 \& 2$ seroprevalence}

Tables 2 and 3 present the seroprevalence and factors associated with HBV, HCV and HTLV $1 \& 2$ in the bivariate and multivariate analyses.

\section{Factors associated with HBV}

The prevalence of HBV among MSM was estimated at 20.4\% (95\% CI: 16.4-25.1). Bivariate analyses showed that the factors associated with HBV infection were reporting multiple sexual partnerships with at least two male partners and a female sexual partner $(p=0.010)$, experiencing condom tearing during anal sex $(p=0.035)$, not using a condom at last anal sex with a main male sexual partner $(p=0.029)$, and being divorced, widowed, married or cohabiting with a woman $(p=0.023)$. Multivariate analysis showed that only not using a condom at last anal sex with a main male sexual partner $(p=0.033)$ and experiencing condom tearing during anal sex $(p=0.012)$ were independently associated with HBV infection (Table 3 ).

\section{Seroprevalence of HCV}

The prevalence of $\mathrm{HCV}$ among MSM is estimated at 11.0\% (95\% CI: 8.0-14.8). Although patterns of disparity were observed according to some characteristics of MSM, bivariate and multivariate analyses with study variables did not reveal any factors associated with HCV infection among MSM (Table 3). 
Table 1 Characteristics of men who have sex with men study participants in Ouagadougou

\begin{tabular}{|c|c|c|c|}
\hline Variables & $n$ & RDS ${ }^{a}$-unadjusted $\%$ & RDS-adjusted \% (95\% Cl $\left.{ }^{\mathrm{b}}\right)$ \\
\hline \multicolumn{4}{|l|}{ Current age (years) } \\
\hline $18-19$ & 78 & 23.7 & $23.6(19.3-28.6)$ \\
\hline $20-24$ & 196 & 59.6 & $60.1(54.7-65.3)$ \\
\hline $25-29$ & 35 & 10.6 & $10.6(7.7-14.5)$ \\
\hline$>=30$ & 20 & 6.1 & $05.6(3.6-08.7)$ \\
\hline Total & 329 & & \\
\hline \multicolumn{4}{|l|}{ Country of birth } \\
\hline Burkina Faso & 272 & 82.7 & $82.7(78.2-86.4)$ \\
\hline Other countries & 57 & 17.3 & $17.3(13.6-21.8)$ \\
\hline Total & 329 & & \\
\hline \multicolumn{4}{|c|}{ Childhood environment } \\
\hline Urban & 288 & 91.4 & $91.4(87.8-94.1)$ \\
\hline Rural & 27 & 8.6 & $8.6(5.9-12.2)$ \\
\hline Total & 315 & 100.0 & \\
\hline \multicolumn{4}{|c|}{ Highest educational level } \\
\hline None or primary & 25 & 7.6 & $7.6(5.1-11.0)$ \\
\hline Secondary & 239 & 72.6 & $72.8(67.7-77.4)$ \\
\hline University & 65 & 19.8 & $19.6(15.7-24.3)$ \\
\hline Total & 329 & 100.0 & \\
\hline \multicolumn{4}{|l|}{ Occupation } \\
\hline Student/pupil & 236 & 71.7 & $72.0(66.9-76.6)$ \\
\hline Employed & 72 & 21.9 & $2.15(17.4-26.3)$ \\
\hline Unemployed & 21 & 6.4 & $6.5(4.2-9.7)$ \\
\hline Total & 329 & & \\
\hline \multicolumn{4}{|c|}{ Marital status (with a woman) } \\
\hline Single & 310 & 94.2 & $94.5(91.5-96.5)$ \\
\hline Other ${ }^{c}$ & 19 & 5.8 & $5.5(3.5-8.5)$ \\
\hline Total & 329 & 100.0 & \\
\hline \multicolumn{4}{|c|}{ Number of biological children } \\
\hline 0 & 305 & 92.7 & $93.0(89.7-95.3)$ \\
\hline$>=1$ & 24 & 7.3 & $7.0(4.7-10.3)$ \\
\hline Total & 329 & 100.0 & \\
\hline \multicolumn{4}{|l|}{ Sexual orientation } \\
\hline Gay/homosexual & 236 & 71.7 & $71.9(66.7-76.5)$ \\
\hline Bisexual & 21 & 6.4 & $6.5(4.42-9.7)$ \\
\hline Heterosexual & 72 & 21.9 & $21.6(17.5-26.5$ \\
\hline Total & 329 & 100.0 & \\
\hline \multicolumn{4}{|l|}{ Anal sex position } \\
\hline Receptive & 19 & 5.8 & $5.7(3.7-8.8)$ \\
\hline Insertive & 310 & 94.2 & $94.3(91.2-96.3)$ \\
\hline Total & 329 & 100.0 & \\
\hline \multicolumn{4}{|c|}{ Number of male anal sex partners } \\
\hline 1 & 75 & 22.9 & $22.9(18.6-27.8)$ \\
\hline 2 & 131 & 39.9 & $40.1(34.9-45.5)$ \\
\hline
\end{tabular}


Table 1 Characteristics of men who have sex with men study participants in Ouagadougou (Continued)

\begin{tabular}{|c|c|c|c|}
\hline Variables & $\mathrm{n}$ & RDS$^{\mathrm{a}}$-unadjusted \% & RDS-adjusted \% $\left(95 \% \mathrm{Cl}^{\mathrm{b}}\right)$ \\
\hline$>=3$ & 122 & 37.2 & $37.0(31.9-42.4)$ \\
\hline Total & 328 & & \\
\hline \multicolumn{4}{|c|}{ Past 12 month STI ${ }^{d}$ symptoms } \\
\hline No & 242 & 73.3 & $73.6(68.6-78.1)$ \\
\hline Yes & 87 & 26.4 & $26.1(21.6-31.1)$ \\
\hline Don't know & 1 & 0.3 & $0.3(0.0-2.2)$ \\
\hline Total & 329 & 100.0 & \\
\hline \multicolumn{4}{|l|}{ HIV status } \\
\hline Negative & 319 & 97.0 & $98.2(96.7-99.0)$ \\
\hline Positive & 10 & 3.0 & $1.8(1.0-3.3)$ \\
\hline Total & 329 & & \\
\hline \multicolumn{4}{|c|}{ Ever injected drugs } \\
\hline No & 323 & 98.2 & $98.2(96.0-99.2)$ \\
\hline Yes & 6 & 1.8 & $1.8(0.8-4.0)$ \\
\hline Total & 329 & & \\
\hline
\end{tabular}

${ }^{a} R D S$ Respondent driven sampling

${ }^{\mathrm{b}} \mathrm{Cl}$ Confidence interval

${ }^{\mathrm{C}}$ Married or cohabiting, divorced, separated

${ }^{d}$ STI Sexually transmitted infection

e HIV Human immunodeficiency virus

\section{Seroprevalence of HDV}

Anti-HDV antibody testing was performed on HBVpositive samples. No participants tested positive for anti-HDV antibodies, meaning that the seroprevalence was $0.0 \%$.

\section{Seroprevalence and correlates of anti-HTLV $1 \& 2$ antibodies}

The results show that the seroprevalence of the HTLV virus in the MSM surveyed is estimated at 4.0\% (95\% CI: 2.3-6.8). In the bivariate analysis, the factors associated with HTLV $1 \& 2$ infection were a history of STI symptoms (genital lesions) during the last 12 months $(p=0.001)$, not using a condom at last anal sex with a main male sexual partner $(p=0.017)$, and not using a condom at last anal sex with a casual male sexual partner $(p=0.018)$. Only the history of genital lesions (penis or anus) during the last 12 months and injection drug use were independently associated with the seroprevalence of anti-HTLV $1 \& 2$ antibodies in the multivariate analysis (Table 3).

\section{Discussion}

To our knowledge, this study is the first in West Africa to report the seroprevalence of hepatitis $\mathrm{B}, \mathrm{C}$, and D and anti-HTLV $1 \& 2$ antibodies among MSM. It shows that the seroprevalence of $\mathrm{HBV}$ and $\mathrm{HCV}$ were very high and that of anti-HTLV $1 \& 2$ antibodies was relatively high.

\section{HBV}

The prevalence of HBV (20.4\%) in our sample of MSM is higher than those reported among other populations in Burkina Faso. In a recent systematic review in Burkina Faso covering the period from 1996 to 2017, the authors estimated the prevalence of $\mathrm{HBV}$ at $9.41 \%$ among the general population, $11.11 \%$ among pregnant women, $11.73 \%$ among blood donors and $12.6 \%$ among people living with HIV [33]. Our results suggest that MSM are a vulnerable group for HBV infection. Modes of transmission other than vertical transmission may explain the high prevalence of HBV among MSM [7, 11, 12]. In this study, the factors associated with HBV infection in the bivariate analysis were for the most part, factors related to sexual behavior, including multiple sexual partnerships with male and female partners, in addition to age $\geq 30$ years and marital status with a woman. Older age had already been identified in some studies as associated with HBV infection $[6,7,34]$, and could be explained by the accumulation of risk of exposure over time and vaccination against HBV coverage, which is increasing among younger individuals. Vaccination against HBV was only introduced in Burkina Faso in 2006 for infants [33].

The majority of MSM in our study identified themselves as gay, but over $44 \%$ reported being bisexual and have sex with men and women, and some are in a conjugal relationship with women. Bisexual MSM could have a higher risk of transmitting and acquiring STI [35], which could explain the higher prevalence of $\mathrm{HBV}$ infection among married MSM. 
Table $2 \mathrm{HBV}^{\mathrm{a}}$, HCV ${ }^{\mathrm{b}}$ and HTLV 1 \&2 seroprevalence by demographic and behavioral characteristics among MSM $^{\mathrm{d}}$ and associated factors in Ouagadougou

\begin{tabular}{|c|c|c|c|c|c|c|c|}
\hline \multirow[t]{2}{*}{ Variables } & \multirow[t]{2}{*}{$n$} & \multicolumn{2}{|l|}{ HBV } & \multicolumn{2}{|l|}{$\mathrm{HCV}$} & \multicolumn{2}{|l|}{ HTLV $1 \& 2$} \\
\hline & & HBV positive & $\begin{array}{l}\text { RDS }^{\mathrm{e}} \text {-adjusted } \\
\text { HBV Positive } \\
\left(95 \% \mathrm{Cl}^{\mathrm{f}}\right)\end{array}$ & $\begin{array}{l}\mathrm{HCV} \\
\text { positive }\end{array}$ & $\begin{array}{l}\text { RDS-adjusted HCV } \\
\text { Positive } \\
(95 \% \mathrm{Cl})\end{array}$ & HTLV1\&2 positive & $\begin{array}{l}\text { RDS-adjusted } \\
\text { HTLV1\&2 Positive } \\
(95 \% \mathrm{Cl})\end{array}$ \\
\hline \multicolumn{8}{|l|}{ Current age (years) } \\
\hline $18-19$ & 78 & 17.9 & $17.7(10.7-27.8)$ & 7.7 & $7.3(3.2-15.5)$ & 3.8 & $3.9(1.3-11.5)$ \\
\hline $20-24$ & 196 & 19.9 & $19.6(14.6-25.7)$ & 13.3 & $13.3(9.2-18.9)$ & 4.1 & $4.1(2.1-8.0)$ \\
\hline $25-29$ & 35 & 22.9 & $23.1(12.0-40.0)$ & 2.9 & $02.9(0.4-18.0)$ & 0.0 & - \\
\hline$>=30$ & 20 & 35.0 & $35.9(18.0-58.9)$ & 15.6 & $16.4(5.4-40.3)$ & 10.0 & $10.9(2.7-34.8)$ \\
\hline Total & 329 & 20.7 & $20.4(16.4-25.1)$ & 10.9 & $11.0(8.0-14.8)$ & 4.0 & $4.0(2.3-6.8)$ \\
\hline \multicolumn{8}{|l|}{ Country of birth } \\
\hline Burkina Faso & 272 & 21.0 & $20.7(16.3-25.9)$ & 9.9 & $09.9(6.9-14.1)$ & 4.0 & $4.1(2.3-7.3)$ \\
\hline Other countries & 57 & 19.3 & $18.8(10.7-31.1)$ & 15.8 & $16.0(8.5-28.1)$ & 3.5 & $3.6(0.9-13.2)$ \\
\hline \multicolumn{8}{|c|}{ Childhood environment } \\
\hline Urban & 288 & 20.3 & $20.0(15.8-25.0)$ & 10.8 & $10.8(7.6-14.9)$ & 4.2 & $4.2(2.4-7.3)$ \\
\hline Rural & 27 & 33.3 & $32.3(17.5-51.7)$ & 14.8 & $15.1(5.7-34.0)$ & 3.7 & $3.8(0.5-22.6)$ \\
\hline \multicolumn{8}{|c|}{ Highest educational level } \\
\hline None or primary & 25 & 24.0 & $24.4(11.4-44.9)$ & 4.0 & $4.1(0.6-24.1)$ & 4.0 & $4.1(0.6-24.1)$ \\
\hline Secondary & 239 & 16.5 & $16.2(12.0-21.4)$ & 11.7 & $11.7(8.1-16.4)$ & 4.2 & $4.2(2.3-7.7)$ \\
\hline University & 65 & 34.8 & $34.5(23.9-46.7)$ & 10.8 & $11.0(5.3-21.4)$ & 3.1 & $3.1(0.8-11.8)$ \\
\hline \multicolumn{8}{|l|}{ Occupation } \\
\hline Student/pupil & 236 & 18.1 & $17.9(13.5-23.3)$ & 12.3 & $12.2(8.6-17.1)$ & 3.8 & $3.8(2.0-7.3)$ \\
\hline Employed & 72 & 28.8 & $28.4(19.2-39.9)$ & 5.6 & $5.7(2.2-14.3)$ & 2.8 & $2.9(0.7-10.8)$ \\
\hline Unemployed & 21 & 22.7 & $21.2(8.9-42.6)$ & 14.3 & $14.3(4.7-36.3)$ & 9.5 & $9.5(2.4-31.3)$ \\
\hline \multicolumn{8}{|c|}{ Marital status (with a woman) } \\
\hline Single & 310 & 19.4 & $19.1(15.1-23.9)$ & 11.0 & $10.9(7.9-15.0)$ & 3.9 & $3.9(2.2-6.8)$ \\
\hline Other ${ }^{g}$ & 18 & 42.1 & $42.7(22.8-65.3)$ & 10.5 & $11.3(2.8-35.7)$ & 5.3 & $5.6(0.8-31.2$ \\
\hline \multicolumn{8}{|c|}{ Number of biological children } \\
\hline 0 & 305 & 20.8 & $20.5(16.3-25.3)$ & 10.5 & $10.5(7.5-14.4)$ & 3.9 & $4.0(2.3-6.9)$ \\
\hline$>=1$ & 24 & 20.8 & $20.1(8.4-40.8)$ & 16.7 & $17.6(6.8-38.6)$ & 4.2 & $4.4(0.6-25.6)$ \\
\hline \multicolumn{8}{|l|}{ Sexual orientation } \\
\hline Gay/homosexual & 236 & 20.3 & $20.1(15.5-25.7)$ & 10.2 & $10.3(7.0-14.9)$ & 3.0 & $3.0(1.4-6.2)$ \\
\hline Bisexual & 21 & 31.8 & $30.5(15.0-52.1)$ & 19.0 & $19.0(7.3-41.3)$ & 4.8 & $4.8(0.7-27.4)$ \\
\hline Heterosexual & 72 & 19.2 & $18.4(11.1-29.0)$ & 11.1 & $10.8(5.4-20.3)$ & 6.9 & $7.1(3.0-16.0)$ \\
\hline \multicolumn{8}{|l|}{ Anal sex position } \\
\hline Receptive & 19 & 26.3 & $26.9(11.6-50.7)$ & 10.5 & $10.8(2.7-34.5$ & 0.0 & 0.0 \\
\hline Insertive & 310 & 20.5 & $20.1(16.0-24.9)$ & 11.0 & $11.0(7.9-15.0)$ & 5.0 & $5.0(2.8-8.9)$ \\
\hline \multicolumn{8}{|c|}{ Tested for $\mathrm{STI}{ }^{\mathrm{h}}$ in the last 12 months } \\
\hline No & 241 & 18.7 & $18.5(14.1-24.0)$ & 12.0 & $12.0(8.4-16.8)$ & 3.8 & $3.4(1.7-6.6)$ \\
\hline Yes & 85 & 27.6 & $26.8(18.5-37.1)$ & 8.2 & $8.4(4.0-16.6)$ & 4.7 & $4.8(1.8-12.2)$ \\
\hline \multicolumn{8}{|c|}{ Past 12 month STI symptoms } \\
\hline No & 311 & 19.6 & $19.4(15.4-24.3)$ & 11.3 & $11.3(8.2-15.3)$ & 2.9 & $2.9(1.5-5.6)$ \\
\hline Yes & 18 & 38.9 & $37.4(18.6-61.0)$ & 5.6 & $5.7(0.8-31.4)$ & 22.2 & $22.8(8.8-47.4)$ \\
\hline \multicolumn{8}{|c|}{ Vaccinated against HBV } \\
\hline No & 264 & 22.7 & $22.4(17.8-27.9)$ & 10.2 & $10.2(7.1-14.5)$ & 3.0 & $3.1(1.5-6.0)$ \\
\hline
\end{tabular}


Table $2 \mathrm{HBV}^{\mathrm{a}}, \mathrm{HCV}^{\mathrm{b}}$ and HTLV $1 \& 2$ seroprevalence by demographic and behavioral characteristics among MSM $^{\mathrm{d}}$ and associated factors in Ouagadougou (Continued)

\begin{tabular}{|c|c|c|c|c|c|c|c|}
\hline \multirow[t]{2}{*}{ Variables } & \multirow[t]{2}{*}{$\mathrm{n}$} & \multicolumn{2}{|l|}{ HBV } & \multicolumn{2}{|l|}{$\mathrm{HCV}$} & \multicolumn{2}{|l|}{ HTLV $1 \& 2$} \\
\hline & & HBV positive & $\begin{array}{l}\text { RDS }^{\mathrm{e}} \text {-adjusted } \\
\text { HBV Positive } \\
\left(95 \% \mathrm{Cl}^{\mathrm{f}}\right)\end{array}$ & $\begin{array}{l}\mathrm{HCV} \\
\text { positive }\end{array}$ & $\begin{array}{l}\text { RDS-adjusted HCV } \\
\text { Positive } \\
(95 \% \mathrm{Cl})\end{array}$ & HTLV1\&2 positive & $\begin{array}{l}\text { RDS-adjusted } \\
\text { HTLV1\&2 Positive } \\
(95 \% \mathrm{Cl})\end{array}$ \\
\hline Yes & 51 & 15.7 & $15.8(8.1-28.6)$ & 13.7 & $13.8(6.7-26.4)$ & 5.9 & $5.9(1.9-16.9)$ \\
\hline Don't know & 14 & 0.0 & - & 14.3 & $14.3(3.6-42.9)$ & 14.3 & $14.3(3.6-42.9)$ \\
\hline \multicolumn{8}{|c|}{ At least 2 sexual partners in the last 12 months } \\
\hline Only males & 268 & 17.9 & $17.7(13.6-22.8)$ & 10.8 & $10.9(7.7-15.3)$ & 4.5 & $4.5(2.6-7.8)$ \\
\hline Males and females & 60 & 33.3 & $33.1(22.3-46.0)$ & 11.7 & $11.4(5.4-22.2)$ & 0.0 & 0 \\
\hline \multicolumn{8}{|c|}{ Type of sexual partners in the last 12 months } \\
\hline Only males & 201 & 19.9 & $19.8(14.8-26.0)$ & 12.9 & $12.9(8.9-18.4)$ & 2.0 & $2.0(0.8-5.3)$ \\
\hline Males and females & 127 & 22.0 & $21.5(15.2-29.5)$ & 7.9 & $7.9(4.3-14.1)$ & 6.3 & $6.3(3.2-12.2)$ \\
\hline \multicolumn{8}{|c|}{ Ever experienced condom tearing during anal sex } \\
\hline No & 218 & 17.4 & $17.4(12.9-23.0)$ & 11.9 & $12.0(8.3-17.1)$ & 4.6 & $4.6(2.5-8.4)$ \\
\hline Yes & 106 & 28.7 & $27.8(20.1-37.0)$ & 9.4 & $9.2(5.0-16.4)$ & 2.8 & $2.9(0.9-8.6)$ \\
\hline \multicolumn{8}{|c|}{ Condom use at last anal sex with a main male partner } \\
\hline No & 54 & 29.6 & $29.9(19.1-43.4)$ & 5.6 & $5.6(1.8-16.1)$ & 9.3 & $9.3(3.9-20.6)$ \\
\hline Yes & 240 & 17.1 & $16.6(12.4-21.9)$ & 11.3 & $11.2(7.8-15.9)$ & 2.1 & $2.1(0.9-5.0)$ \\
\hline \multicolumn{8}{|c|}{ Condom use at last anal sex with a casual male partner } \\
\hline No & 34 & 17.6 & $17.9(8.2-34.6)$ & 11.8 & $11.9(4.5-27.9)$ & 8.8 & $8.9(2.9-24.4)$ \\
\hline Yes & 224 & 19.6 & $19.2(14.5-24.9)$ & 10.3 & $10.4(7.0-15.2)$ & 3.6 & $3.6(1.8-7.1)$ \\
\hline \multicolumn{8}{|l|}{ HIV status } \\
\hline Positive & 10 & 40.0 & $40.0(15.7-70.4)$ & 10.0 & $11.0(8.0-14.9)$ & 0 & 0.0 \\
\hline Negative & 319 & 20.1 & $20.1(16.0-24.8)$ & 11.0 & $10.0(1.4-47.0)$ & 4.1 & $4.1(2.4-6.9)$ \\
\hline \multicolumn{8}{|l|}{ Ever injected drugs } \\
\hline No & 323 & 20.7 & $20.5(16.4-25.3)$ & 11.0 & $11.2(8.1-15.1)$ & 3.7 & $3.8(2.1-6.5)$ \\
\hline Yes & 6 & 16.7 & $16.7(2.3-63.4)$ & 0.0 & - & 16.7 & $16.7(2.3-63.4)$ \\
\hline
\end{tabular}

${ }^{\mathrm{a}} \mathrm{HBV}$ Hepatitis B virus

${ }^{\mathrm{b}} \mathrm{HCV}$ Hepatitis $\mathrm{C}$ virus

${ }^{c} H T L V$ Human T-cell leukemia virus

${ }^{\mathrm{d}}$ MSM Men who have sex with men

${ }^{\mathrm{e}} R D S$ Respondent driven sampling

${ }^{\mathrm{f}} \mathrm{Cl}$ Confidence interval

${ }^{9}$ Married or cohabiting, divorced, separated

${ }^{\mathrm{h}} \mathrm{STI}$ Sexually transmitted infection

'HIV Human immunodeficiency virus

Multivariate analysis in our study showed that only condom use at last anal sex with a main male sexual partner $(p=0.033)$ and condom tearing during anal sex $(p=0.012)$ were independently associated with HBV infection, suggesting transmission of the virus through high-risk sex.

\section{HDV}

In our study, no HBsAg-bearing MSM was infected with HDV. A prior study found a $0.1 \%$ (95\% CI: $0.06-0.23$ ) HDV prevalence among men in general population of Burkina Faso [36]. The very low prevalence in our study could be explained by the small size of the sample. However, although the number of positive HBsAg samples analyzed in our study is low, zero seroprevalence of anti-HDV antibodies has also previously been reported by studies in Sub-Saharan Africa. An analysis of 49 pregnant women with HBsAg in Burkina Faso revealed no evidence of anti-HDV antibodies [37]. Similarly, in Mozambique, Cunha et al., in their study of 146 blood donors infected with HBV, found no positive cases of anti-HDV antibodies [38].

\section{$\mathrm{HCV}$}

West Africa is considered an area with a high prevalence of $\operatorname{HCV}[39,40]$. We found in our study a prevalence of $11 \%$ in MSM. This prevalence is three times higher than that reported in Burkina Faso, and in West Africa in 


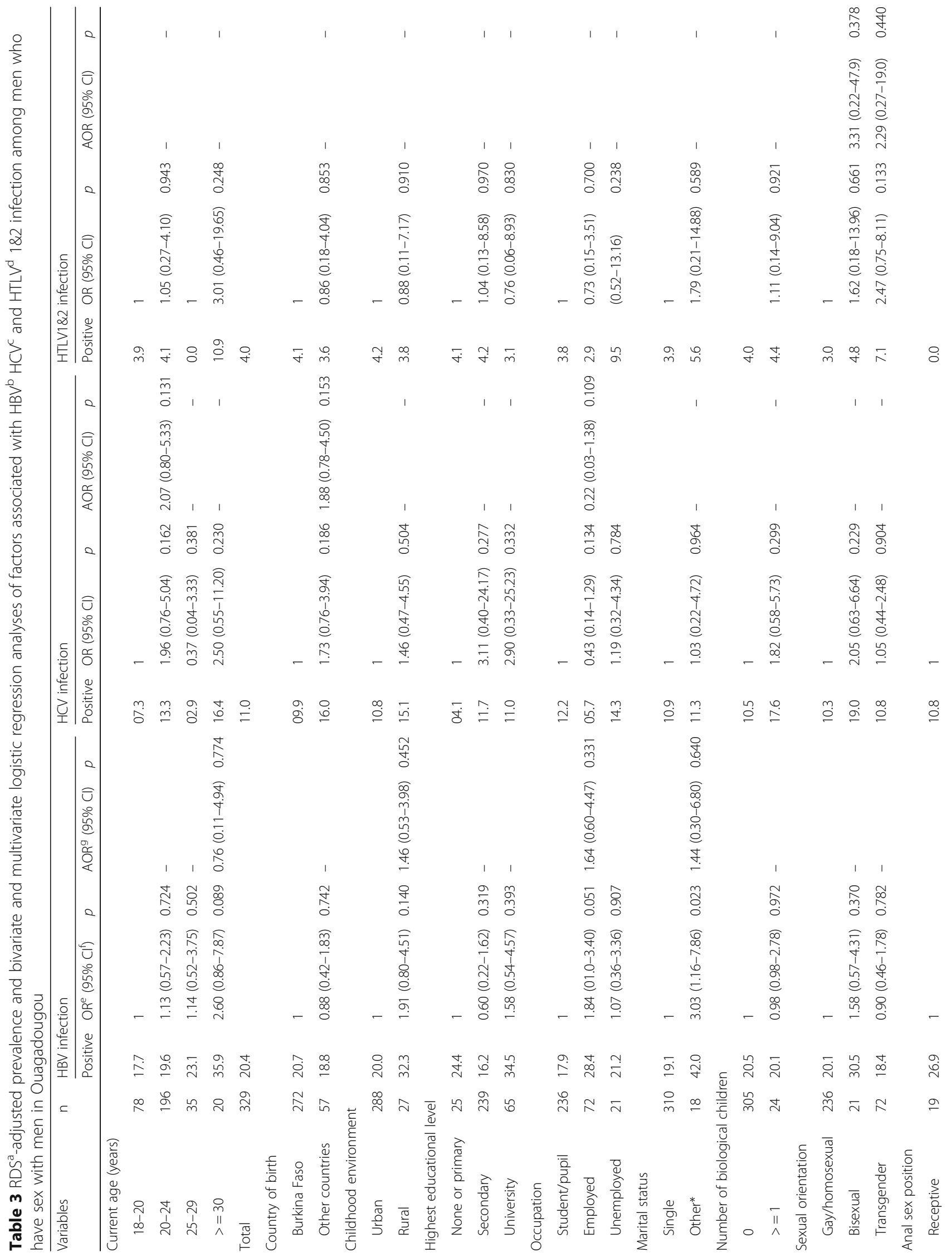




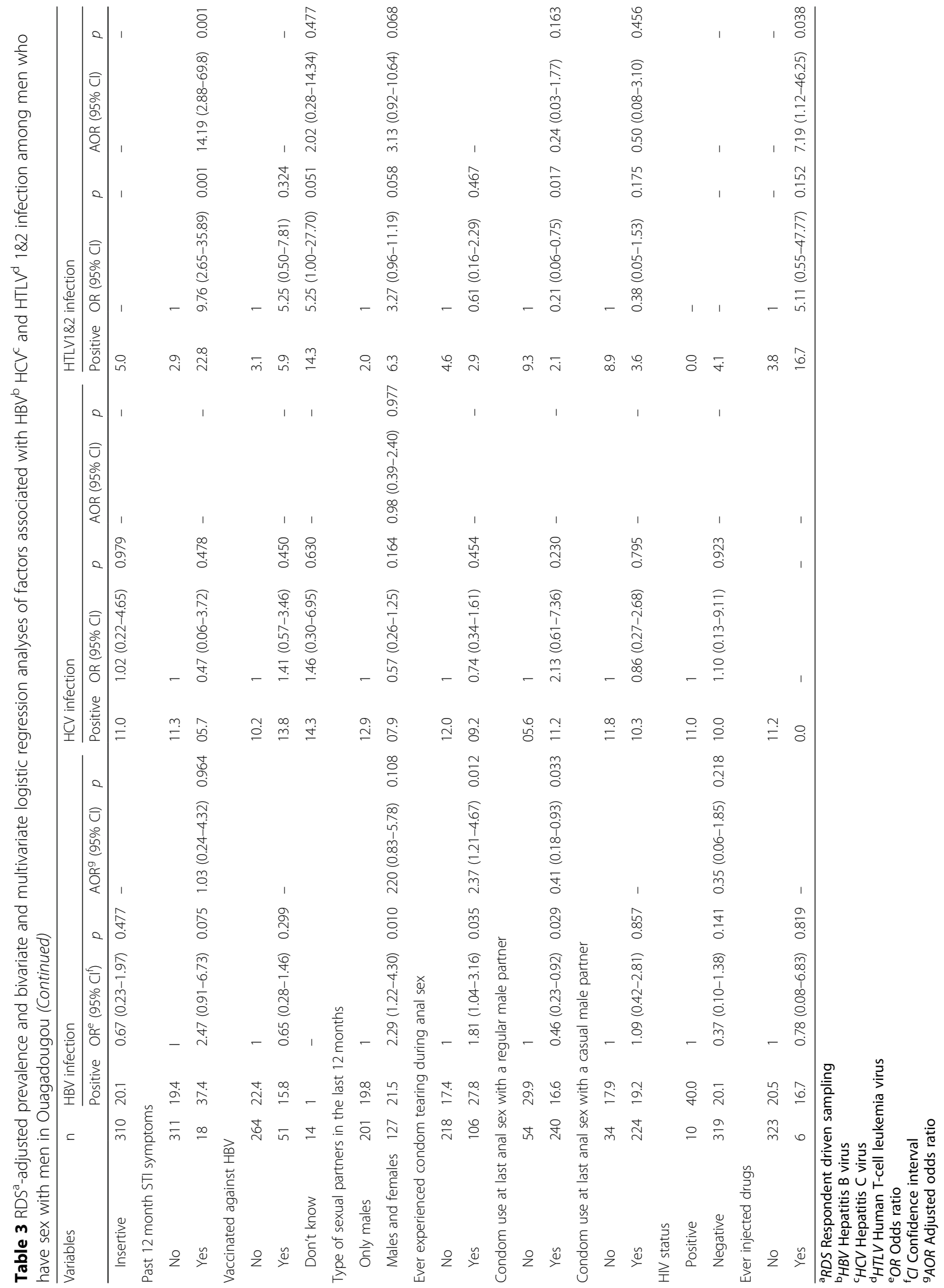


general. An analysis of the blood samples collected during the 2010 Demographic and Health Survey in the Burkinabe population estimated the $\mathrm{HCV}$ prevalence at $3.6 \%$ [41]. Systematic reviews have also estimated the pooled prevalence of $\mathrm{HCV}$ in the West African population between 3 and 5\% [39, 42]. HCV transmission is mainly through blood, especially through transfusion with contaminated blood or nosocomial transmission with contaminated material [18]. Among MSM, there is often an increased risk of infection from injection drug use and HIV infection $[8,9,43,44]$. In a recent systematic review, the authors found that the prevalence of anti-HCV antibodies was estimated at 40 and $6.7 \%$, respectively, among HIV-positive MSM who were injection drug users and non-drug users [45]. Furthermore, traumatic anal sex may be involved in $\mathrm{HCV}$ transmission among MSM.

\section{HTLV $1 \& 2$ seroprevalence}

HTLV 1\&2 viruses are probably among the most neglected bloodborne viruses among MSM in Africa, and data are very scarce. This first study of MSM in Burkina Faso shows that the overall seroprevalence of anti-HTLV $1 \& 2$ antibodies was $4 \%$. This seroprevalence is higher than those reported among pregnant women in West Africa, especially in Burkina Faso in 2006 (1.02\%), in Côte d'Ivoire in 1989 (1.9\%), and in Ghana in 2006. (2.1\%) [23]. More recently in Nigeria, Yuguda et al. reported a seroprevalence of $3.2 \%$ among blood donors in Nigeria, with all positive cases being male [46]. The high prevalence of anti-HTLV $1 \& 2$ antibodies in MSM in our study may be explained by risk behaviors $[26,47]$. The factors independently associated with the presence of anti-HTLV $1 \& 2$ antibodies in our study were a history of genital lesions (penis or anus) during the last 12 months and injection drug use. Other authors have found that HTLV infection in MSM is associated with the presence of STI including syphilis or genital lesions [14, 48, 49], or injection drug use. In a study in Argentina among people who inject drugs, MSM, sex workers, and tuberculosis patients, the authors found an overall prevalence of antiHTLV $1 \& 2$ antibodies of $2.4 \%$, and the highest prevalence (19.1\%) was among people who inject drugs [27].

Our study has a number of limitations. Participants may have underreported sensitive behaviors, including injection drug use, which is punishable by law in Burkina Faso. The study was cross-sectional, therefore it is unknown whether the identified risk factors preceded the associated infections. Also, in this seroprevalence study, the testing was based on serological methods using fourth generation ELISA. Even these methods have very high specificity and sensitivity, a positive HBsAg or HCV and HTLV antibody test does not confirm the stage of infection during the study. Finally, there are specific limitations to the RDS method. The RDS financial incentive, while modest, may encourage more low-income MSM to participate in the study and lead to selection bias. Despite these limitations, RDS was identified during the preparatory phase of data collection as the best approach to recruiting MSM in this context. In addition, our study provides the first seroprevalence data for hepatitis B, C, and D and HTLV viruses among MSM in Burkina Faso. These data fill a gap and will help map the epidemiology of these infections among high-risk populations in Africa.

\section{Conclusions}

This first study shows that MSM in Burkina Faso are heavily affected by hepatitis B and C viruses and HTLV infection. However, no MSM in this study tested positive for HDV. Sexual behavioral factors, genital or anal lesions, and injection drug use may play an important role in the spread of these viruses among MSM, particularly HBV and HTLV. These results highlight the need to strengthen the prevention of STI generally among MSM, but specifically the prevention of HBV transmission through vaccination. Sexual health education, strengthening accessibility of condoms and condom-compatible lubricants, and integrated STI services in HIV programs for MSM should be considered. Similarly, interventions to increase awareness of the risks associated with injecting drugs should be undertaken among MSM to limit the spread of HTLV.

\section{Abbreviations \\ AOR: Adjusted odds ratio; CERS: Ethics Committee for Health Research of Burkina Faso; Cl: Confidence interval; ELISA: Enzyme Linked Immunoassay; HBsAg: Hepatitis B virus surface Antigen; HBV: Hepatitis B virus; HCV: Hepatitis C virus; HDV: Hepatitis D virus; HIV: Human immunodeficiency virus; HRP: Horseradish peroxidase; HTLV 1\&2: Human T-cell leukemia virus types 1 and 2; Ig: Immunoglobilin; MSM: Men who have sex with men; OR: Odds ratio; RDS: Respondent driven sampling; RDSAT: RDS Analysis Tool; TMB/ H2O2: Tetra-methyl-benzidine/hydrogen peroxyde; USD: United States dollars}

\section{Acknowledgments}

The authors would like to acknowledge the entire MSM community in Burkina Faso for their participation in the present study, the facilitators and the data collectors, the Permanent Secretary of the National Council against AIDS and STI (SP/CNLS-IST) of Burkina Faso, PAMAC, AIDSETI-network of Burkina Faso and especially the Association African Solidarity (AAS) and REVS+.

\section{Funding}

The biological sample and behavioral data are from the Research To Prevention (R2P) project, which is funded by the US Agency for International Development under Contract No. GHH-I-00-0700, 032-00, supported by the USA President's Emergency Plan for AIDS Relief. The R2P Project is led by the Johns Hopkins Center for Global Health and managed by the Johns Hopkins Bloomberg School of Public Health Center for Communication Programs. Reagents for hepatitis B, C, D virus and HTLV $1 \& 2$ testing were provided by Institut de Recherche en Sciences de la Santé (IRSS), Ouagadougou, Burkina Faso.

\section{Availability of data and materials}

The datasets used during the current study are available from the corresponding author on reasonable request. 


\section{Authors' contributions}

$\mathrm{HGO}, \mathrm{SK}, \mathrm{NB}$, SB conceived and designed the study; HGO, MC, CD performed lab analysis; $\mathrm{HGO}$ prepared the manuscript and it was reviewed by SK, NB, $A G, C R, T Y, R O, S B$. All authors read and approved the final manuscript

\section{Ethics approval and consent to participate}

The study received ethical approval from the Ethics Committee for Health Research (CERS) of Burkina Faso. Participants provided written informed consent.

\section{Consent for publication}

Not applicable.

\section{competing interests}

The authors declare that they have no competing interests.

\section{Publisher's Note}

Springer Nature remains neutral with regard to jurisdictional claims in published maps and institutional affiliations.

\section{Author details}

'Biomedical and Public Health Department, Institut de Recherche en Sciences de la Santé (IRSS), Ouagadougou 03BP7192, Burkina Faso. ${ }^{2}$ University Ouaga1 Joseph Ki-Zerbo, Ouagadougou, Burkina Faso. ${ }^{3}$ Institut Africain de Santé Publique, Ouagadougou, Burkina Faso. ${ }^{4}$ Department of Epidemiology, Johns Hopkins Bloomberg School of Public Health, Baltimore, MD, USA.

Received: 6 August 2018 Accepted: 19 December 2018

Published online: 29 December 2018

\section{References}

1. Goodreau SM, Golden MR. Biological and demographic causes of high HIV and sexually transmitted disease prevalence in men who have sex with men. Sex Transm Infect. 2007;83:458-62 [cited 2018 May 1] Available from: https://www.ncbi.nlm.nih.gov/pmc/articles/PMC2598698/.

2. Mason K, Ketende S, Peitzmeier S, Ceesay N, Diouf D, Loum J, et al. A CrossSectional Analysis of Population Demographics, HIV Knowledge and Risk Behaviors, and Prevalence and Associations of HIV Among Men Who Have Sex with Men in the Gambia. AIDS Res Hum Retroviruses. 2013;29:1547-52 [cited 2017 Nov 1] Available from: http://online.liebertpub.com/doi/abs/10 1089/aid.2013.0092.

3. Ross MW, Nyoni J, Ahaneku HO, Mbwambo J, McClelland RS, SA MC. High HIV seroprevalence, rectal STIs and risky sexual behaviour in men who have sex with men in Dar es Salaam and Tanga, Tanzania. BMJ Open. 2014;4 [cited 2018 May 1] Available from: https://www.ncbi.n/m.nih.gov/pmc/ articles/PMC4156794/.

4. Wade AS, Kane CT, Diallo PAN, Diop AK, Gueye K, Mboup S, et al. HIV infection and sexually transmitted infections among men who have sex with men in Senegal. AIDS Lond Engl. 2005;19:2133-40.

5. MacGregor L, Martin NK, Mukandavire C, Hickson F, Weatherburn P, Hickman M, et al. Behavioural, not biological, factors drive the HCV epidemic among HIV-positive MSM: HCV and HIV modelling analysis including HCV treatment-as-prevention impact. Int J Epidemiol. 2017;46:1582-92.

6. Oliveira MP, Matos MAD, Silva ÁMC, Lopes CLR, Teles SA, Matos MA, et al. Prevalence, Risk Behaviors, and Virological Characteristics of Hepatitis B Virus Infection in a Group of Men Who Have Sex with Men in Brazil: Results from a Respondent-Driven Sampling Survey. PLoS One. 2016;11:e0160916.

7. Pitasi MA, Bingham TA, Sey EK, Smith AJ, Teshale EH. Hepatitis B virus (HBV) infection, immunity and susceptibility among men who have sex with men (MSM), Los Angeles County, USA. AIDS Behav. 2014;18(Suppl 3):248-55.

8. Price H, Gilson R, Mercey D, Copas A, Parry J, Nardone A, et al. Hepatitis C in men who have sex with men in London - a community survey. HIV Med. 2013;14:578-80 [cited 2018 Apr 30] Available from: https://www.ncbi.nlm. nih.gov/pmc/articles/PMC4016752/.

9. Semugoma NP, Rebe K, Sonderup MW, Kamkeumah M, De Swardt G,

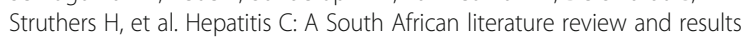
from a burden of disease study among a cohort of drug-using men who have sex with men in Cape Town, South Africa. S Afr Med J. 2017;107:1116 [cited 2018 May 1] Available from: http://www.samj.org.za/index.php/samj/ article/view/12144.
10. Urbanus AT, van de Laar TJ, Stolte IG, Schinkel J, Heijman T, Coutinho RA, et al. Hepatitis $C$ virus infections among HIV-infected men who have sex with men: an expanding epidemic. AIDS Lond Engl. 2009;23:F1-7.

11. Wahome E, Ngetsa C, Mwambi J, Gelderblom HC, Manyonyi GO, Micheni M, et al. Hepatitis B Virus Incidence and Risk Factors Among Human Immunodeficiency Virus-1 Negative Men Who Have Sex With Men in Kenya. Open Forum Infect Dis. 2017;4 [cited 2018 May 1] Available from: https:// academic.oup.com/ofid/article/4/1/ofw253/2632201.

12. Wang $C$, Wang $Y$, Huang $X$, Li X, Zhang $T$, Song $M$, et al. Prevalence and factors associated with hepatitis $B$ immunization and infection among men who have sex with men in Beijing, China. PloS One. 2012;7:e48219.

13. Paiva A, Casseb J. Sexual transmission of human T-cell lymphotropic virus type 1. Rev Soc Bras Med Trop. 2014;47:265-74 [cited 2016 May 17] Available from: http://www.scielo.br/scielo.php?script=sci_arttext\&pid= S0037-86822014000300265\&lng=en\&nrm=iso\&tlng=en.

14. Zunt JR, La Rosa AM, Peinada J, Lama JR, Suarez L, Pun M, et al. Risk factors for HTLV-II infection in Peruvian men who have sex with men. Am J Trop Med Hyg. 2006;74:922-5 [cited 2016 May 17] Available from: http://www. ncbi.n/m.nih.gov/pmc/articles/PMC2695970/

15. WHO. Global hepatitis report. Geneva: World Health Organization; 2017. 2017 Apr p. 83. Report No.: ISBN 978-92-4-156545-5

16. Nelson NP, Easterbrook PJ, BJ MM. Epidemiology of Hepatitis B Virus Infection and Impact of Vaccination on Disease. Clin Liver Dis. 2016;20:60728 [cited 2018 May 2] Available from: https://www.ncbi.n/m.nih.gov/pmc/ articles/PMC5582972/.

17. Rizzetto M. Hepatitis D Virus: Introduction and Epidemiology. Cold Spring Harb Perspect Med. 2015;5 [cited 2018 May 2] Available from: https://www. ncbi.nlm.nih.gov/pmc/articles/PMC4484953/.

18. Moosavy SH, Davoodian P, Nazarnezhad MA, Nejatizaheh A, Eftekhar E, Mahboobi H. Epidemiology, transmission, diagnosis, and outcome of Hepatitis C virus infection. Electron Physician. 2017;9:5646-56 [cited 2018 May 2] Available from: https:/www.ncbi.nlm.nih.gov/pmc/articles/PMC5718874/.

19. Hagan $H$, Jordan $A E$, Neurer J, Cleland CM. Incidence of sexually transmitted hepatitis $C$ virus infection in HIV-positive men who have sex with men. AIDS Lond Engl. 2015;29:2335-45.

20. Wandeler G, Gsponer T, Bregenzer A, Günthard HF, Clerc O, Calmy A, et al. Hepatitis C virus infections in the Swiss HIV Cohort Study: a rapidly evolving epidemic. Clin Infect Dis Off Publ Infect Dis Soc Am. 2012;55:1408-16.

21. HTLV-I [Internet]. Inst. Pasteur. [cited 2016 May 17]. Available from: http:// www.pasteur.fr/fr/institut-pasteur/presse/fiches-info/htlv-i

22. Masson E. Rétrovirus humains HTLV-1 et HTLV-2 [Internet]. EM-Consulte. [cited 2016 May 17]. Available from: http://www.em-consulte.com/article/ 28182/retrovirus-humains-htlv-1-et-htlv-2

23. Gessain A, Cassar O. Epidemiological Aspects and World Distribution of HTLV-1 Infection. Front Microbiol. 2012;3 [cited 2018 May 13] Available from: https://www.ncbi.nlm.nih.gov/pmc/articles/PMC3498738/.

24. Gonçalves DU, Proietti FA, Ribas JGR, Araúijo MG, Pinheiro SR, Guedes AC, et al. Epidemiology, Treatment, and Prevention of Human T-Cell Leukemia Virus Type 1-Associated Diseases. Clin Microbiol Rev. 2010;23:577-89 [cited 2018 May 13] Available from: https:/www.ncbi.nlm.nih.gov/pmc/articles/PMC2901658/.

25. Human T-Cell Lymphotropic Viruses: Background, Pathophysiology, Epidemiology. 2017 [cited 2018 May 14]; Available from: https://emedicine. medscape.com/article/219285-overview

26. Prasetyo AA, Sari Y. Human T-lymphotropic virus-1/2 detected in drug abused men who have sex with men in Surakarta Indonesia. AIP Conf Proc. 2017;1813:020001 [cited 2018 May 14] Available from: https://aip.scitation. org/doi/abs/10.1063/1.4975939.

27. Berini CA, Pando MA, Bautista $C T$, Eirin ME, Martinez-Peralta $L$, Weissenbacher $M$, et al. HTLV-1/2 among high-risk groups in Argentina: molecular diagnosis and prevalence of different sexual transmitted infections. J Med Virol. 2007;79:1914-20.

28. Catalan-Soares BC, Almeida RT, Carneiro-Proietti AB. Prevalence of HIV-1/2, HTLV-I/II, hepatitis B virus (HBV), hepatitis C virus (HCV), Treponema pallidum and Trypanosoma cruzi among prison inmates at Manhuaçu, Minas Gerais State, Brazil. Rev Soc Bras Med Trop. 2000;33:27-30.

29. Heckathorn DD. Respondent-Driven Sampling: A New Approach to the Study of Hidden Populations. Univ Calif Press Behalf Soc Study Soc Probl. 1997:44:174-99.

30. Tiffany JS. Respondent-Driven Sampling in Participatory Research Contexts: Participant-Driven Recruitment. J Urban Health. 2006:83:113-24 [cited 2016 Jun 23] Available from: http://link.springer.com/10.1007/s11524-006-9107-9. 
31. Heckathorn DD. Respondent-Driven Sampling II: Deriving Valid Population Estimates from Chain-Referral Samples of Hidden Populations. Soc Probl. 2002;49:11-34 [cited 2017 Oct 2] Available from: https://academic.oup.com/ socpro/article-lookup/doi/10.1525/sp.2002.49.1.11.

32. Weller S, Davis K. Condom effectiveness in reducing heterosexual HIV transmission. Cochrane Database Syst Rev. 2002;(1):CD003255. [cited 2017 Nov 1] Available from: https://www.ncbi.nlm.nih.gov/pubmed/11869658.

33. High prevalence of hepatitis B infections in Burkina Faso (1996-2017): a systematic review with meta-analysis of epidemiological studies. [cited 2018 May 9]. Available from: https://www.ncbi.nlm.nih.gov/pmc/articles/ PMC5921387/

34. Hepatitis B Infection and Association with Other Sexually Transmitted Infections Among Men Who Have Sex with Men in Peru. [cited 2018 May 13]. Available from: https://www.ncbi.n/m.nih.gov/pmc/articles/ PMC2912599/

35. Sexual Orientation Disparities in Sexually Transmitted Infections: Examining the Intersection Between Sexual Identity and Sexual Behavior. [cited 2018 Aug 1]. Available from: https:/www.ncbi.nlm.nih.gov/pmc/articles/ PMC3575167/

36. Etude ANRS 12270 : prévalence du VHCNHB en population générale au Burkina-Faso | Vih.org. [cited 2018 May 23]. Available from: http://vih.org/ 20160423/etude-anrs-12270-prevalence-du-vhcvhb-en-population-generaleau-burkina-faso/138077

37. Andernach IE, Leiss LV, Tarnagda ZS, Tahita MC, Otegbayo JA, Forbi JC, et al. Characterization of Hepatitis Delta Virus in Sub-Saharan Africa. J Clin Microbiol. 2014;52:1629-36 [cited 2018 May 15] Available from: http://jcm. asm.org/content/52/5/1629.

38. Use of replacement blood donors to study the epidemiology of major blood-borne viruses in the general population of Maputo, Mozambique. PubMed - NCBI [Internet]. [cited 2018 May 15]. Available from: https://www. ncbi.nlm.nih.gov/pubmed/17935167.

39. Karoney MJ, Siika AM. Hepatitis C virus (HCV) infection in Africa: a review. Pan Afr Med J. 2013;14 [cited 2018 May 13] Available from: https://www. ncbi.nlm.nih.gov/pmc/articles/PMC3612901/.

40. Layden JE, Phillips R, Opare-Sem O, Akere A, Salako BL, Nelson K, et al. Hepatitis C in Sub-Saharan Africa: Urgent Need for Attention. Open Forum Infect Dis. 2014;1 [cited 2018 May 13] Available from: https://academic.oup. com/ofid/article/1/2/ofu065/1466359.

41. Meda $N$. Prévalence des hépatites virales $B$ et $C$ en population générale au Burkina Faso. Brussels: résultats préliminaires de l'étude ANRS 12270; 2016.

42. Madhava V, Burgess C, Drucker E. Epidemiology of chronic hepatitis C virus infection in sub-Saharan Africa. Lancet Infect Dis. 2002;2:293-302 [cited 2018 May 13] Available from: https:/www.thelancet.com/journals/laninf/article/ PIIS1473-3099(02)00264-5/abstract.

43. Aceijas C, Rhodes T. Global estimates of prevalence of HCV infection among injecting drug users. Int J Drug Policy. 2007;18:352-8 [cited 2016 Apr 12] Available from: http://linkinghub.elsevier.com/retrieve/pii/ S0955395907000916

44. Lea T, Lee E, Mao L, de Wit J, Holt M. HIV and hepatitis C virus co-infection among men who have sex with men in Sydney, and associations with sexual and drug use practices. Sex Health. 2013;10:448-51.

45. Jordan AE, Perlman DC, Neurer J, Smith DJ, Des Jarlais DC, Hagan $H$. Prevalence of hepatitis $C$ virus infection among HIV+ men who have sex with men: a systematic review and meta-analysis. Int J STD AIDS. 2017;28:145-59 [cited 2018 May 13] Available from: https://doi.org/10.1177/0956462416630910.

46. Yuguda S, Manga MM, Fowotade A, Chukwuma OE, Aken' OY. Seroprevalence of Human T-Cell Lymphoma/Leukemia Virus Type-1 (HTLV1) Antibodies among Blood Donors at Ibadan, Nigeria. J Hum Virol Retrovirol. 2017;5(5):00169. https://doi.org/10.15406/jhvrv.2017.05.00169.

47. Vahidnia F, Stramer SL, Kessler DA, Krysztof DE, Dodd RY, Notari E, et al. Risk factors and epidemiology of human T-lymphotropic virus types 1 and 2 in US blood donors. Retrovirology. 2015;12:P84 [cited 2018 May 14] Available from: https://doi.org/10.1186/1742-4690-12-S1-P84

48. Ma Y, Zheng S, Wang N, Duan Y, Sun X, Jin J, et al. Epidemiological Analysis of HTLV-1 and HTLV-2 Infection among Different Population in Central China. PLOS ONE. 2013;8:e66795 [cited 2018 May 13] Available from: http:// journals.plos.org/plosone/article?id=10.1371/journal.pone.0066795.

49. HIV-1, HBV, HCV, HTLV, HPV-16/18, and Treponema pallidum infections in a sample of Brazilian men who have sex with men. - PubMed - NCBI [Internet]. [cited 2018 May 14]. Available from: https://www.ncbi.nlm.nih. gov/pubmed/25083768.

Ready to submit your research? Choose BMC and benefit from:

- fast, convenient online submission

- thorough peer review by experienced researchers in your field

- rapid publication on acceptance

- support for research data, including large and complex data types

- gold Open Access which fosters wider collaboration and increased citations

- maximum visibility for your research: over $100 \mathrm{M}$ website views per year

At $\mathrm{BMC}$, research is always in progress.

Learn more biomedcentral.com/submissions 